\title{
乳牛の泌乳期に和ける血清総コレステロール值と疾病発生との関連
}

\author{
大笹 清*1) 阿部哲男*1) 飯嶋良朗*1) 佐々木大樹*1) 牛島 巧*2) 権 五鏡*3) \\ (昭和 62 年 9 月 18 日受理)
}

\begin{abstract}
Relationship between Serum Total Cholesterol and Morbidity in Lactating
Holstein Cows

Kryoshi Osasa (Taiki Agricultural Mutual Aid Association, Taiki-cho, Hokkaido 089-21) Tetsuo Abe, Yoshiaki Ijjima, Daju Sasaki,

TAKumi Ushijima and Gokyo Kweon
\end{abstract}

\begin{abstract}
SUMMARY
Serum total cholesterol(T-CHO) were determined in a total of 715 lactating Holstein cows during a period from January to April, 1983. Parity, days after calving and milk yield influenced TCHO level significantly. TDN and CP levels in the ration, as well as body weight, were not significant factors. Morbidity was a factor for changes in T-CHO level. This level decreased significantly in cows with diseases. There was no marked difference in T-CHO level between cows with diseases and healthy ones.
\end{abstract}

要 約

1983 年 1 月から 4 月までの期間にのベ 715 頭（7 牛舎）のホルスタイン種泌乳牛の T-CHO 值 を測定し，これに対し影響を与える要因を共分散分析を用いて調査し，また，T-CHO 值と疾病発 生との関連について, 判別関数により検討を加えた.

産次, 分姢後の日数, 泌乳量および疾病の発生は T-CHO 值に有意な影響を与え, 体重, TDN および CP 充足率は有意な影響を与えなかった。

つぎに, 産次, 分婏後の日数および泌乳量を考慮し, T-CHO 值により非疾病発生牛と疾病発生 牛との判別を試みたが不可能であった。すなわち, 疾病発生によって T-CHO 值は低下するが, T-CHO 值により非疾病発生牛と疾病発生牛とを区別することができなかった.

乾乳期に括ける血清総 コレステロール值（以下 $\mathrm{T}$ CHO 值) と分娩後の疾病発生との関係については, SOMMER $^{15)}$ と LOTTHAMMER $ら^{8)}$, 権ら ${ }^{4)}$ および安倍ら ${ }^{2)}$ の報告があり，彼らは乳牛に括ける分婏後の疾病発生の 予防診断として乾乳期における $\mathrm{T}$ - CHO 值が重要な意 義をるつことを指摘した.

しかし, 泌乳牛における $\mathrm{T}-\mathrm{CHO}$ 值と疾病発生との 関係についての報告は見当たらない，そこでわれわれ は，泌乳期に和ける T-CHO 值と疾病発生との関係を 明らかにする目的で調査を行い，検討を加えたのでその 結果を報告する.

*1) 北海道大樹町農業共済組合 (広尾郡大樹町下大樹)

*2) 北海道大樹町農業共済組合〔現. 大樹町農業協同 組合（広尾郡大樹町一条通）]

*3) 帯広畜産大学畜産学部〔現. 北海道大学獣医学部 (札幌市北区18条西 9 丁目)]

\section{1. 調査期間および対象牛}

1983 年 1 月 18 日から, 同年 4 月 28 日までの期間 に, 北海道広尾郡大樹町内各地から選出した 7 戸の農家 に飼養されている 262 頭のホルスタイン種搾乳牛を用い て調査を行った.なお, 調查は調查期間中毎月 1 回行っ たので, 調査対象牛は延べ 715 頭となった. 1982 年に 括ける調査対象農家別の搾乳牛 1 頭当たりの年間平均乳 量は $7,000 \sim 8,800 \mathrm{~kg}$ (平均 $7,900 \mathrm{~kg}$ ) であった. な掞. 大樹町全体の搾乳牛 1 頭当たりの年間平均乳量は 6,540 kgであった.

\section{2. 調査方 法}

1）上記調査期間に乳牛各個体について, 産次, 体重, 分娩後の日数, 泌乳量, 給与飼料中の DM, TDN, お よび CP の量, NRC 飼養標準を用いた TDN および

日獣会誌 $40 \quad 775 \sim 778 \quad$ （1987） 
乳牛の泌乳期に括ける血清総コレステロール值と疾病発生との関連

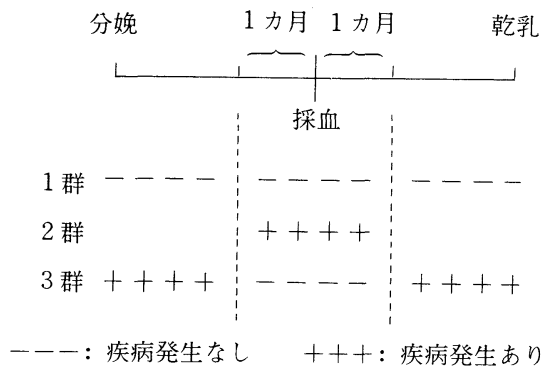

図 1 疾病群の分類

CP の充足率および疾病の発生状況を調査した。また， 毎月 1 回調査時に各農家ごとに泌乳牛全頭の採血を行 い, T-CHO 值を酵素法で測定した。

2） T-CHO 值と産次, 体重, 分婏後の日数, 泌乳量, TDN 充足率, CP 充足率拈よび疾病発生状況との関連 性を共分散分析を用いて検討した。

3）つぎに，産次，分婏後の日数および泌乳量を考慮 したらえで, 非疾病発生牛と疾病発生牛とを $\mathrm{T}-\mathrm{CHO}$ 值 を用いて分類でさるかを判別関数を用い検討した.

疾病については各採血直前の分娩から乾乳までのもの で, 大樹町農業共済組合の診療簿に記載されているもの を調査し，対象牛を疾病発生状況から以下のように 3 群 に分類した（図 1).

1 群: 採血直前の分娩から採血直後の乾乳までの間 に疾病発生のなかったもの.

2 群: 採血前 1 力月から採血後 1 力月の間に疾病発 生のあったもの（採血前後 1 カ月の期間外の疾病発生の 有無は問わない).

3 群 : 採血直前の分婏から採血直後の乾乳までの期 間に疾病発生のあったものの中で，採血前後 1 力月の間 に疾病発生のなかったもの.

したがって, 同一牛が採血時期により別の群に分類さ れる場合がある。また，疾病群を 2 群に分類したのは, 疾病発生牛は正常牛より T-CHO 值が低くなるが, 4 〜 週間でその差がなくなる ${ }^{6)}$ から, 疾病発生と採血の 間の期間が長い場合, 非疾病発生牛と差がでなくなる可 能性を考えたからである。

給与飼料については, 給与洔の重量を計測し, 残飼分 を差し引いて給与量とした，残飼は一番乾草のみで，給 与量の 0 ～ $20 \%$ であった。 また，各農家ごとに飼料の 成分分析を行い, 給与飼料中の $\mathrm{DM}, \mathrm{TDN}$ および CP 值を計算した. 泌乳量, 体重については大樹町乳牛改良 検定組合で行っている検定の成績を用いた，統計処理に は SAS（北海道大学大型計算機センター）を使用し た.

\section{3. 結}

果

調査対象牛の調査項目の今回調査した範囲は表 1 に示

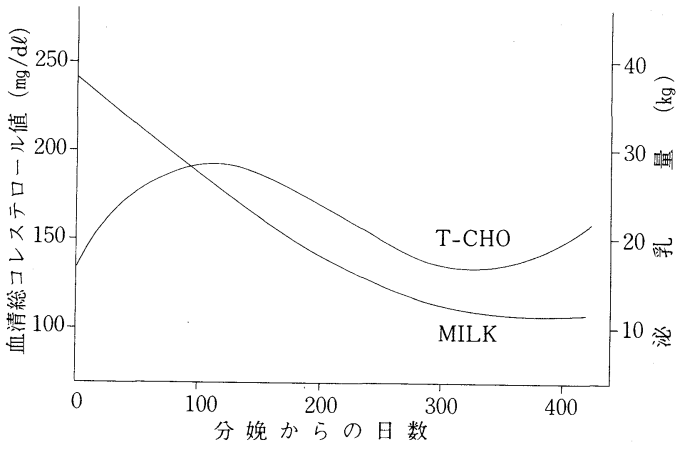

図 2 血清総コレステロール值・泌乳量と分婏から の日数の関係

した. また, 疾病発生状況は, 繁殖障害（卵巣および子 宮疾患）が全疾病中 $34.3 \%$, 分娩時およびその後発生 する疾病（難産, 胎盤停滞, 産裖熱, 産後起立不能症, ケトン症および第四胃変位）が同 $27.0 \%$ ，また乳房炎 が同 $14.9 \%$ であった。

分娩後の日数と $\mathrm{T}-\mathrm{CHO}$ 值および泌乳量との関係を 図 2 に示した。

共分散分析の結果, T-CHO 值は産次, 疾病発生状況, 分娩後の日数および泌乳量と関係があった（表 2 ). ま た，T-CHO 值（Yijk） は表 3 の式で表わされる.

1） T-CHO 值と産次との関係（表 4)：T-CHO 值 は初産が 1 番高く, その後, 6 産目まで減少する. 初産 は 2 度目より約 $9 \mathrm{mg} / \mathrm{d} l$ 高かった。

\section{表 1 調査対象牛の調查項目の範囲}

\begin{tabular}{|c|c|}
\hline 血清総コレステロール値 & $56 \sim 328 \mathrm{mg} / \mathrm{d} l$ \\
\hline 次 & 1～9 産目 \\
\hline 重 & $520 \sim 900 \mathrm{~kg}$ \\
\hline 分婏後の日数 & $1 \sim 521$ 日 \\
\hline 泌 乳 量 & $4 \sim 52 \mathrm{~kg}$ \\
\hline TDN 充足率 & $54 \sim 145 \%$ \\
\hline CP 充 足率 & $40 \sim 145 \%$ \\
\hline
\end{tabular}

表 2 血清総コレステロール値の変動要因

\begin{tabular}{lcc}
\hline \hline & MEAN SQUARE & F VALUE \\
\hline PARITY & $4,347.72$ & $2.58^{* *}$ \\
IX & $11,566.42$ & $6.87^{* *}$ \\
FROMC & $160,899.19$ & $95.51^{* *}$ \\
FROM 2 & $97,904.65$ & $58.12^{* *}$ \\
FROM 3 & $60,624.29$ & $35.99^{* *}$ \\
MILK & $1,009.39$ & 0.60 \\
MILK 2 & $15,794.28$ & $9.38^{* *}$ \\
MILK 3 & $19,155.14$ & $11.37^{* *}$ \\
ERROR & $1,684.65$ &
\end{tabular}

注) PARITY: 産次 IX: 疾病発生状況 FROMC: 分婏後の日数 FROM 2: 分婏後の日数 FROM 3: 分婏後の日数 MILK: 泌乳量 MILK 2: 泌乳 量 MILK 3: 泌乳量 $\quad * *: \mathrm{P}<0.01$ 
表 3 共分散分析による血清総コレステロール 值 $\left(\mathrm{Y}_{\mathrm{i} J \mathrm{Jk}}\right)$ の式

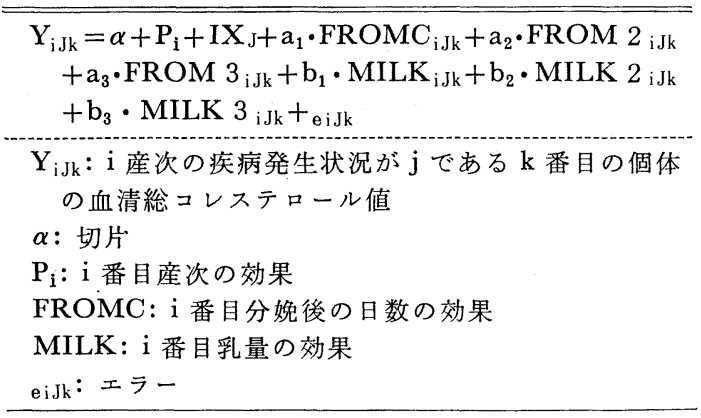

表 4 血清総コレステロール值変動要因の効果

\begin{tabular}{lcc}
\hline \hline INTERCEPT $(\alpha)$ & & 13.27 \\
PARITY $(\mathrm{P})$ & 1 & 23.98 \\
& 2 & 14.80 \\
& 3 & 13.63 \\
& 4 & 9.91 \\
& 5 & 8.48 \\
& 6 & 3.13 \\
& 7 & 7.12 \\
& 8 & -7.33 \\
IX & 9 & 0.00 \\
& $(\mathrm{j})$ & \\
& 1 & 14.23 \\
& 2 & 3.98 \\
FROMC & 3 & 0.00 \\
FROM2 & & 1.29 \\
FROM3 & & -0.0050 \\
MILK & & 0.000006 \\
MILK2 & & -0.56 \\
MILK3 & & 0.2577 \\
\hline
\end{tabular}

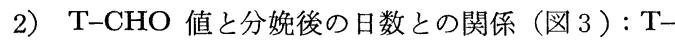
$\mathrm{CHO}$ 值は分娩後 200 日まで増加し, その後 350 日まで 減少する，そして 350 日以降ふたたび増加する.

3） T-CHO 值と泌乳量との関係(図 4)：T-CHO 值 は乳量 $45 \mathrm{~kg}$ までは増加し，それ以上になると減少す る.

4） T-CHO 值と疾病群との関係(表 4): $\mathrm{T}-\mathrm{CHO}$ 值 は疾病発生の 2 群や 3 群より, 疾病発生のない 1 群の方 が約 $10 \sim 14 \mathrm{mg} / \mathrm{d} l$ 高かった.

また，体重，TDN 充足率和よび CP 充足率は T-CHO 值に対して有意な影響を与えなかった。なお，今回の決 定係数は 0.383 であった.

つぎに, 産次, 分婏後の日数抒よび泌乳量を考慮した らえで, 非疾病発生牛と疾病発生牛とを $\mathrm{T}-\mathrm{CHO}$ 值を 用いて判別を試みた結果, 正しく判別された確立は，1 群 $80.8 \%$ ，2群 $15.9 \% ， 3$ 群 $26.7 \%$ であった。判別

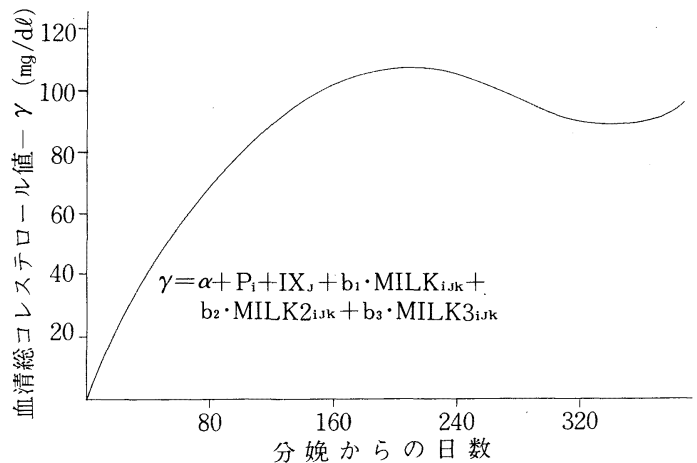

図3 血清総コレステロール値と分婏からの日数の 関係（共分散分析処理による）

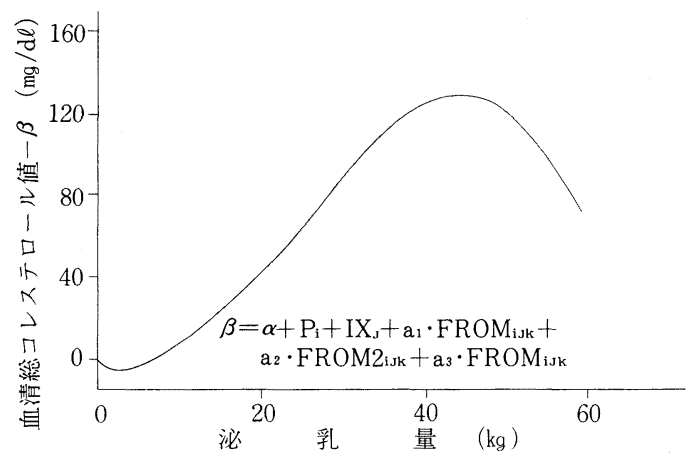

図 4 血清総コレステロール值と泌乳量との関係 （共分散分析処理による）

表 5 疾病群の判別

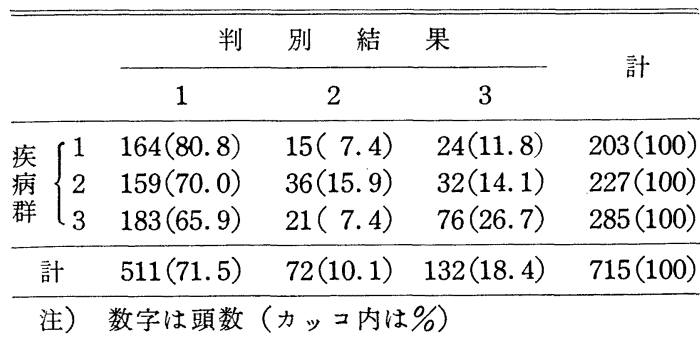

結果は各群では異なった判別をした場合より高い率であ ったが, 疾病発生の 2 群や 3 群の誤判別率が高いため に, T-CHO 值による非疾病発生牛と疾病発生牛との判 別は困難であった（表 5 ).

すなわち，T-CHO 值と疾病発生との関係は, 疾病発 生により T-CHO 值は低下するが, T-CHO 值による 非疾病発生牛と疾病発生牛との判別は不可能であった。

\section{4. 考察}

$\mathrm{T}-\mathrm{CHO}$ 值と年歯に関する報告は多くあるが1,3,7,9,11 14), 搾乳牛の年齢（産次）で比較した報告は少なく, RowLANDS ら ${ }^{12)}$, SINGH ら ${ }^{13)}$ にるのみである. RowLANDS らは 2 産目の T-CHO 值は 3 産目以上の值 
乳牛の泌乳期に打ける血清総コレステロール值と疾病発生との関連

より高いと報告しており, 今回の結果と一致している.

しかし, SINGH らは 34〜59 カ月跉雑種泌乳牛を調査し た結果，年齢と T-CHO 值との間に相関はなかったと 報告し, 今回の結果と異なっている.この原因は地域, 季節, 泌乳量, 品種, 分姢後の日数などの影響によるも のと考えられる.

$\mathrm{T}-\mathrm{CHO}$ 值と乳期（分姢後の日数）に関しては分娩後 T-CHO 值は増加し，6〜10 週で最高值を示すとの報告 がある ${ }^{5 \sim 7,10,12)}$. この最高值の時期は図 2 に示したよう に, T-CHO 值と分娭後の日数を単純に比較した今回の 結果と近いものである. しかし, 図 3 に示した T-CHO 值に対する乳量, 産次などの影響を除いた T-CHO 值と 分婏後の日数との関係とは, 最高值の時期が大きくずれ ている.このように，T-CHO 值に影響をおよぼす要因 を除かずに比較したために，今回の結果と異なっている と考える. また，ARAVE ら"，SINGH ら ${ }^{13)}$ は T-CHO 值と乳期との間には相関関係があると報告し, 今回の結 果と一致している.

これまでの報告の多くは年 7,9 14), T-CHO 值を検討 する場合, T-CHO 值に影響を与える要因を一つと考光, 他の要因による影響を考慮していない，今回の結果との 相違の最大の原因は， T-CHO 值に影響を与えている他 の要因のためと考学る. 今後, 泌乳牛の T-CHO 值に 検討を加光る場合には, 変動要因を十分に考慮する必要 があると考える。

疾病発生により T-CHO 值は低下するのに, 非疾病発 生牛と疾病発生牛との判別関数による判別が， T-CHO 值でできなかったのは, 非疾病発生牛と疾病発生牛との T-CHO 值の分布の重なりが大きかったためめにでた結 果と考える.

〔本研究の要旨は, 昭和 61 年度北海道獣医師学会（岩
見沢市)で発表した.」

本調査に対してご助言をたまわり，本文を校閲してい ただいた帯広畜産大学家畜生産科学科の小野斉教授, ならびに統計処理を打願いした同. 寺脇良悟先生に深甚 なる謝意を表する。

\section{引用文献}

1) Arave, C. W., Miller, R. H. and Lamb, R. C.: J. Dai. Sci., 58, 423〜427 (197b).

2) 安倍健彦, 安里 章, “山本克俊, ほか: 日獣会誌 (学会号) 36, 166 (1983).

3) Edfors-Lilja, I., Gahne, B., Lundstorm, K., et al.: Swedish J. Agric. Res., 8, 113 122 (1978).

4) 権 五鏡, 小野 斉, 福井 豊, ほか: 北獣会誌 27, 189 (1983).

5) 権 五鏡, 小野 斉, 岩住安晃 : 北獣会誌, 28, $251 \sim 254$ (1984).

6) 権 五鏡, 小野 斉, 山科秀也, ほか：北獣会誌, 29, 54 60 (1985).

7) Lennon, H. D. Jr. and Mrxner, J. P.: J. Dai. Sci., 40, 1424 1429 (1957).

8) Lotthammer, K. H., V. Benten, K. and El Nahas, H.: Praktishe Tierarzt, 13, 563 567 (1971).

9) Murthy, T. S. and Rao, A. V. N.: Indian Vet. J., 58, 771 773 (1981).

10) Prakash, B. S. and Tandon, R. N.: Indian J. Anim. Sci., 49, 308 309 (1979).

11) Purohit, M. K. and Kohli, I. S.: Indian Vet. J. 54, 268〜270 (1977).

12) Rowlands, G. J., Manston, R., Stark, A. J., et al.: J. Agric. Sci. Camb., 94, 517 527 (1980).

13) Singh, S. R. and Eapen, K. J.: Indian J. Dai. Sci., 32, 29 31 (1979).

14) Sinha, R. K., Thakuria, B. N., Baruah, R. N., et al.: Indian Vet. J., 58, 529 533 (1981).

15) Sommer, H.: Vet. Med. Rev., 1/2, 42 63 (1975).

\section{ミート ピ ア 創造の 詩 \\ 笹 崎龍雄著 46 判上製本 320 頁 定価 1,800 円（宁 300 円）}

獣医 師 笹 崎 龍 雄 氏 $の$ 世界!!

日本の養豚産業振興の旗手として，まっしぐらに歩んで来た業界の第一人者，笹崎龍雄氏の「ミートピア」創 造に注ぐ情熱のすべてを語り尽くした感動の書.

《主 要 目 次》 I. 使命観の自覚 II.生きものに学ぶ(豚声人語) III.多くの仲間と共に $\mathrm{N}$.泉ごころ （豚とのロマン） V.ミートピア創造の旅 V. 花開くミートピア UI. 豚児と共に（私のあゆみ）

$$
\text { 発行所株式会社商業界 }
$$

東京都港区麻布台 2-4-9 TEL 03-584-7311 振替 東京 6-4019 